\title{
THE ANALYSIS OF OPTIMAL CRACK RATIO FOR PWR PRESSURE VESSEL CLADDING USING GENETIC ALGORITHM
}

\author{
Mike Susmikanti ${ }^{1}$, Roziq Himawan ${ }^{1}$, Jos Budi Sulistyo ${ }^{2}$ \\ ${ }^{1}$ Center for Nuclear Reactor Technology and Safety, National Nuclear Energy Agency, Puspiptek, \\ Tangerang \\ ${ }^{2}$ Center for Nuclear Facilities Engineering, National Nuclear Energy Agency, Puspiptek, Tangerang \\ Email:mike@batan.go.id \\ Diterima editor: 23 Januari 2018 \\ Diperbaiki: 16 Februari 2018 \\ Disetujui untuk publikasi: 19 Februari 2018
}

\begin{abstract}
THE ANALYSIS OF OPTIMAL CRACK RATIO FOR PWR PRESSURE VESSEL CLADDING USING GENETIC ALGORITHM. Several aspects of material failure have been investigated, especially for materials used in Reactor Pressure Vessel (RPV) cladding. One aspect that needs to be analyzed is the crack ratio. The crack ratio is a parameter that compares the depth of the gap to its width. The optimal value of the crack ratio reflects the material's resistance to the fracture. Fracture resistance of the material to fracture mechanics is indicated by the value of Stress Intensity Factor (SIF). This value can be obtained from a J-integral calculation that expresses the energy release rate. The detection of the crack ratio is conducted through the calculation of J-integral value. The Genetic Algorithm (GA) is one way to determine the optimal value for a problem. The purpose of this study is to analyze the possibility of fracture caused by crack. It was conducted by optimizing the crack ratio of AISI 308L and AISI 309L stainless steels using GA. Those materials are used for RPV cladding. The minimum crack ratio and JIntegral values were obtained for AISI 308L and AISI 309L. The SIF value was derived from the JIntegral calculation. The SIF value was then compared with the fracture toughness of those material. With the optimal crack ratio, it can be predicted that the material boundaries are protected from damaged events. It can be a reference material for the durability of a mechanical fracture event.
\end{abstract}

Keywords: Fracture mechanics, RPV cladding, J-Integral, Stress Intensity Factor, Genetic Algorithm

\section{ABSTRAK}

ANALISIS RASIO RETAK OPTIMAL UNTUK KELONGSONG BEJANA TEKAN PWR MENGGUNAKAN ALGORITMA GENETIKA. Banyak aspek kegagalan material telah diteliti, terutama untuk bahan yang digunakan pada kelongsong bejana tekan reaktor (RPV). Salah satu aspek yang perlu dianalisis adalah rasio retak. Rasio retak adalah parameter yang membandingkan kedalaman celah dengan lebarnya. Nilai optimal rasio retak mencerminkan ketahanan material terhadap patahan. Ketahanan material terhadap mekanika patahan ditunjukkan oleh nilai Stress Intensity Factor (SIF). Nilai ini dapat diperoleh dari perhitungan J-integral yang mengekspresikan tingkat pelepasan energi. Deteksi rasio retak dilakukan melalui perhitungan nilai J-integral. Algoritma Genetika (GA) adalah salah satu cara untuk menentukan nilai optimal suatu masalah. Tujuan dari penelitian ini adalah untuk menganalisis kemungkinan patah yang disebabkan oleh retak dengan menganalisis rasio retak baja tahan karat AISI 308L dan AISI 309L dengan GA. Bahan tersebut digunakan untuk kelongsong RPV. Rasio retak optimal dan nilai J-Integral diperoleh untuk AISI 308L dan AISI 309L. Nilai SIF berasal dari perhitungan J-Integral. Nilai SIF kemudian dibandingkan dengan ketangguhan retak material tersebut. Dengan rasio retak optimal, dapat diprediksi batas rasio retak sehingga terlindung dari kejadian patah. Hal ini dapat menjadi bahan referensi untuk ketahanan dari mekanika patahan.

Kata kunci: Mekanika Patahan, Kelongsong Bejana Tekan Reaktor, J-Integral, Faktor Intensitas Tegangan, Algoritma Genetik

DOI: $10.17146 / \mathrm{tdm} \cdot 2018.20 .1 .4082$ 


\section{INTRODUCTION}

The Reactor Pressure Vessel (RPV) cladding is an important system and component in a nuclear power plant. The RPV cladding experiences heavy load processes that can cause fracture. The material that are used is an important factor in determining whether fracture occurs. The use of poor property material increases fracture risk. Therefore, material testing is necessary. Besides temperature and radiation effects, the material experiences loads. The failure of material can be caused by corrosion, fatigue, or fracture. It is necessary to assess the strength of the material. In fracture mechanics, the stress intensity factor (SIF) value is one of the parameters that reflect the resistance of a material towards fracture. The SIF value is determined through J-integral calculation.

The phenomenon of fracture mechanics is reflected in the crack ratio through J-Integral value. The crack ratio is the ratio between crack depth and crack width. The crack ratio is expected to a minimum. The minimum allowable crack ratio has to be known in order to avoid fracture. The optimal calculation for a complex function with analysis is very difficult to be done. The Genetic Algorithm (GA) is an efficient optimization tool for both maximum and minimum problems for a complex function. The crack ratio and J-Integral can be optimized using GA.

The prospect and limitation of a fracture mechanic tool were reviewed for failure analysis [1]. The 3-D SIF has been evaluated for a crescent crack in a spherical pressure vessel [2]. The effects of temperature on microstructure and mechanical properties were analyzed for SA-508 Gr. 4N steel [3]. The SIF for mode-I fatigue crack was determined by using finite element analysis [4]. Furthermore, 3-D SIF was calculated for coplanar crack arrays and ring cracks in a spherical pressure vessel [5]. The prospect and limitation of a fracture mechanic tool were reviewed for failure analysis. A simple method has been used to calculate the SIF for complex 3-D cracks at a notch [6]. The SIF for semi-elliptical cracks with high aspect ratio was computed by using the tetrahedral finite element [7]. The SIF was calculated for embedded elliptical cracks in cylindrical and spherical vessels [8]. In addition, GA was applied to optimize crack detection for the beam structures [9]. In another study, the residual stress in high-temperature treatment was optimized using GA and Neural Network [10]. Finally, the mechanical fracture of PWR pressure vessel was evaluated and modeled based on neural network [11].

Based on the previous studies, it appears that the optimization of crack ratio has not been conducted for the Pressurized Water Reactor (PWR) pressure vessel cladding with materials of American Iron and Steel Institute (AISI) 308L and AISI 309L stainless steel. Those materials consist of high-chrome and steel that are appropriate for pressure vessel cladding. The difficulty to optimize the crack ratio is an important problem.

The objective of this study is to optimize crack ratio based on the detection of crack aspect ratio and SIF using GA for PWR pressure vessel cladding. The cladding materials studied were 308L and AISI 309L stainless steel. The SIF values were obtained through J-integral.

\section{THEORY}

Fracture mechanic is a field concerned with the study of mechanical behavior of cracked materials subjected to an applied load. The process of rupture is due to the displacement of nucleation and growth of cracks. One of the types of crack is the semi-elliptic crack. The semielliptic crack is described in Figure 1 [7, 11]. 


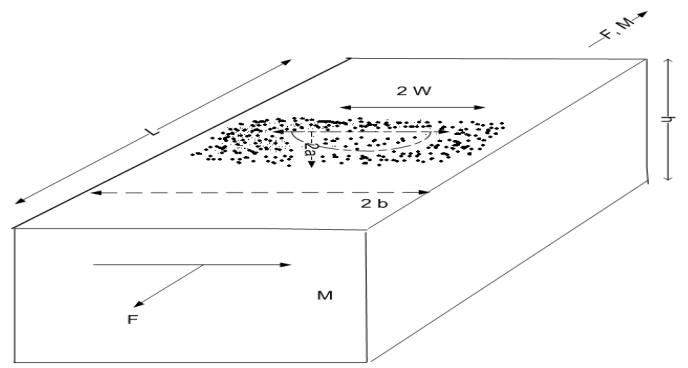

Figure 1. Crack distribution

There are three types of crack symptoms. The first type is the mode I, or opening mode, where the crack surfaces are pulled apart in the $y$ direction. The deformations are symmetric with respect to the plane's $y$ and $z$ axes. For each mode, crack extension may only take place in the direction of the $x$ axis, which is the original orientation of the crack. The mode I crack with the direction of crack is described in Figure 2 [4].

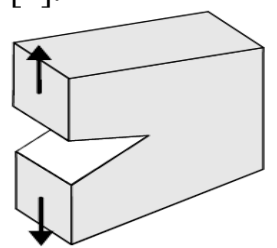

Figure 2. The direction of crack in 3-D (Mode-1 fracture) [4].

The Stress Intensity Factor, $K_{I}$, is a fracture mechanic parameter to predict the stress value near the tip of a crack caused by a load. The value of Stress Intensity Factor is determined by stress crack level, crack geometry, and material geometry. The fracture toughness is a value of material resistance to fracture. In the crack analysis, Stress Intensity Factor is compared with fracture toughness $K_{I C}$. The stability of crack propagation distribution could be determined by comparing the value of $K_{I}$ with $K_{I C}$. If the value $K_{I}$ is greater than $K_{I C}$, it means that the material structure is not in a safe condition [11].

The energy release rate can be expressed as a path-independent line integral, called the Jintegral. To analyze the relationship of Stress Intensity Factor, crack ratio, and fracture toughness, the J-integral can be calculated numerically or using finite element method. Furthermore, for optimization purpose, the J-integral can be calculated using genetic algorithm $[9,10]$. In elastic plastic fracture mechanics, J-integral is used to evaluate the crack. The value of J-integral is evaluated around crack front in the form of the stress value. However, it is difficult to optimize crack ratio using finite element method. The pressure vessel cladding is assumed as the cantilever beam. The J-integral in 3-D especially is expressed in Equation (1) [12].

$$
J=1.8624 r^{2}-3.95 r^{3}-16.375 r^{4}-37.226 r^{5}+76.81 r^{6}-126.9 r^{7}+172 r^{8}-143.97 r^{9}+66.56 r^{10}
$$

here $r=a / h$, where $a / h$ is a crack ratio; $a$ is the depth of crack and $h$ is the depth or thickness of the beam $[7,12]$.

After obtaining the value of a J-integral, the SIF can be calculated by using the relationship equation between SIF and J-integral. The SIF is expressed in Equation (2) [11].

$$
K_{I}=\sqrt{\frac{E}{1-v^{2}} J}
$$

where $E$ is Young's modulus, $v$ is the value of Poisson's ratio, $J$ is the value of the J-Integral.

The fracture toughness, $K_{I C}$, is a material property that describes the ability of a material containing a crack to resist fracture. Each material has a different characteristic of fracture toughness. This value is obtained from experimental research. The critical crack size in the material 
was determined by comparing the value of SIF and the material's fracture toughness. If the SIF is less than the fracture toughness value, it means that the material still has resistance against fracture [11].

The genetic algorithm is an adaptive heuristic search algorithm based on evolutionary ideas of natural selection and genetics. GA simulates the survival of the fittest individuals over consecutive generations to solve a problem. The initial population is randomly generated. Each generation consists of a population of a character string that is analogous to the chromosome as found in human DNA. Each individual represents a point in search space and a possible solution. The individuals in the population are then made to go through a process of evolution. The algorithm evolves through three operators, namely selection, crossover, and mutation operator. Each individual is modified through the use of random crossing back recombination (crossover) and displacement (mutation) to form a new generation. The new generation of the chosen solution is then used in the next iteration. The results of the repetition of the above steps are expressed in a set of binary numbers or binary digits in the range of (binary digit/bit) as well as in the ranks of real numbers (the real). The algorithm ends when the maximum number of generations has been produced, or the best approximation level has been reached $[9,10]$.

The parameters to be specified in GA include the parameters that control the size of the population declared ( $p o p$ size), probability of recombination/crossover $(p c)$, and probability of mutation ( $\mathrm{pm}$ ). The use of a constant value of $p c$ and $p m$ is to maintain the variety, and which pc or pm value is used depends on the problem. The selection method is stochastic sampling. In this method, the selection probability of individuals depends on the fitness value, starting with the largest probability for the largest fitness value. The largest fitness value is taken most frequently so as to have the best chance to reproduce [10].

\section{METHODOLOGY}

The base metals of cladding were AISI 309L and AISI 308L. In this study, the cantilever beam had a length of $\mathrm{L}$, height $\mathrm{h}$, and width $\mathrm{b}$. Each material had different properties. The Poisson's ratio ( $v$ ) was 0.28 and Young's modulus (E) was $200 \times 103 \mathrm{MPa}$ for AISI 308L. The Poisson's ratio was in the range of $0.27-0.30$ and Young's modulus was in the range of (190 $210) \times 103 \mathrm{MPa}$ for AISI 309L. In this study, J-integral calculations of crack in RPV cladding were modeled as a beam with semi-elliptic surface crack as shown in Figure 3.

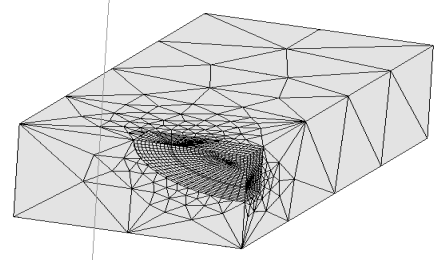

Figure 3. Rectangular beam with semi elliptic surface crack for cladding

The chemical composition of AISI 308L stainless steel is described in Table 1.

Table 1. The composition of elements chemical stainless steel AISI 308L

\begin{tabular}{cc}
\hline Element & Weight (\%) \\
\hline $\mathrm{C}$ & 0.03 \\
$\mathrm{Si}$ & 1.00 \\
$\mathrm{Mn}$ & 2.00 \\
$\mathrm{P}$ & 0.045 \\
$\mathrm{~S}$ & 0.03 \\
$\mathrm{Ni}$ & 13 \\
$\mathrm{Cr}$ & 20 \\
$\mathrm{~S}$ & 0.03 \\
$\mathrm{Fe}$ & 60 (at least) \\
\hline
\end{tabular}


Table 2 describes chemical composition of AISI 309L stainless steel,

Table 2. The composition of elements stainless steel AISI 309L

\begin{tabular}{cc}
\hline Element & Weight (\%) \\
\hline $\mathrm{C}$ & 0.02 \\
$\mathrm{Si}$ & 1.00 \\
$\mathrm{Mn}$ & 2.00 \\
$\mathrm{P}$ & 0.2 \\
$\mathrm{~S}$ & 0.03 \\
$\mathrm{Ni}$ & 14 \\
$\mathrm{Cr}$ & 23 \\
$\mathrm{~S}$ & 0.03 \\
$\mathrm{Fe}$ & 60 (at least) \\
\hline
\end{tabular}

For the optimization problem, the J-integral calculations were performed numerically using Equation (1). The optimization of a crack ratio and the evaluation of J-integral used GA. The population size (pop size) for simulation must be at least greater than or equal to 30 . The crack ratio was constrained into a certain range $0<a / h<1$. It was calculated with a GA program in MATLAB. The inputs are a crack ratio and the J-Integral function as shown in Equation (1).

Afterward, the SIF for AISI 308L and AISI 309L were calculated from the optimal Jintegral value using each material's Poisson's ratio and Young's modulus with Equation (2). The SIF values were then compared with the fracture toughness of the materials. Those steps are shown in the flow diagram in Figure 4.

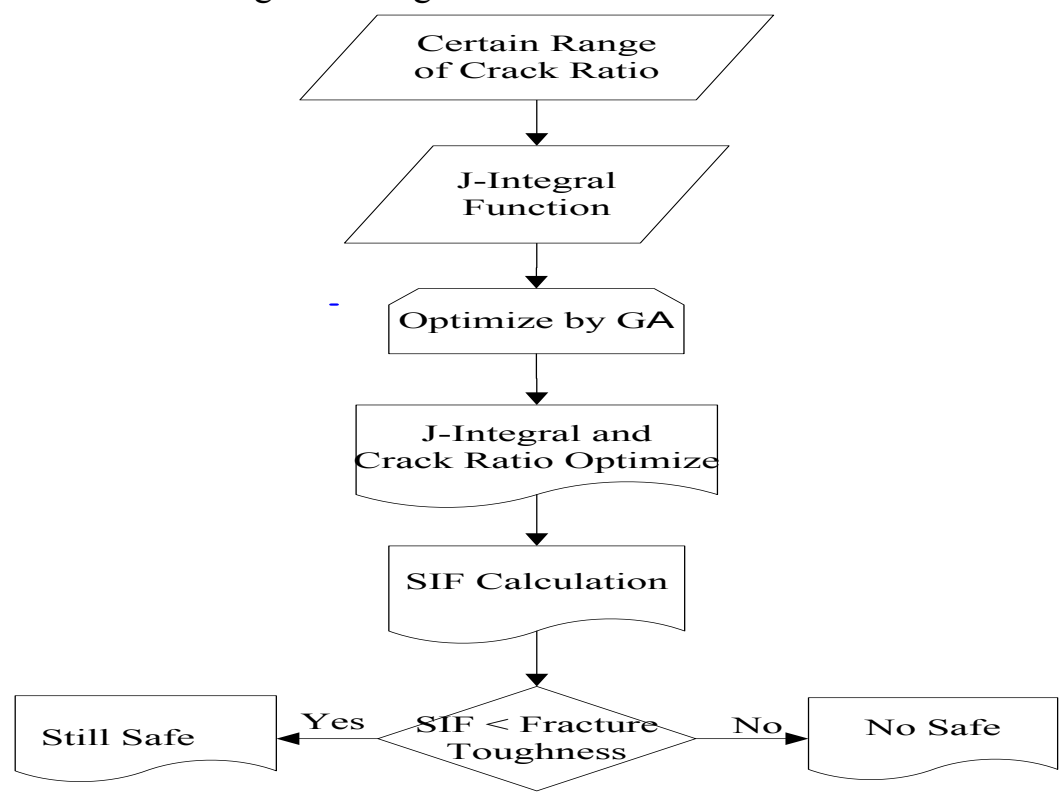

Figure 4. Process of J-integral and crack ratio optimization

\section{RESULTS AND DISCUSSION}

The reason for using GA is that there is a difficulty to find the maximum of higher-order polynomials such as the J-Integral through optimization criteria using differentiation. In addition, as shown in Figure 5, at the crack ratio in the range of 0.05 to 0.3, it appears that it is difficult to determine the maximum value of J-Integral. However, by interpolation, the maximum integral was obtained as 0.0182 while the crack ratio was 0.15 . 
The GA can optimize J-integral using Eq. (1). The $x$ axis represents crack ratio $r=a / h$ that is in the range of $0<a / h<1$ [9]. In this simulation, $a / h$ takes values in $0.05<a / h<0.95$ where parameter $a$ is the depth of crack and $h$ is the depth or the thickness of the beam. To determine the parameters in the GA, including the parameters that control the size of the population declared must be at least 30; here, it was set to 50 . The crack ratio was defined by the setting parameter from 0.05 . to 0.95 . The number of generation was defined by setting $n$ to 5 . The values of parameter $p c$ (probability of crossover) was 0.90 and $\mathrm{pm}$ (probability of mutation) were 0.01 , depending on the completion size of the scope of the fitness value. This is to maintain the variety, adjustment and determined the problem-solving. The selection method was a stochastic sampling. In this method, surviving individuals were selected based on their fitness values, the individuals with the higher fitness values being set as a higher probability, and vice versa. The largest fitness value is taken in order to have a chance to reproduce.

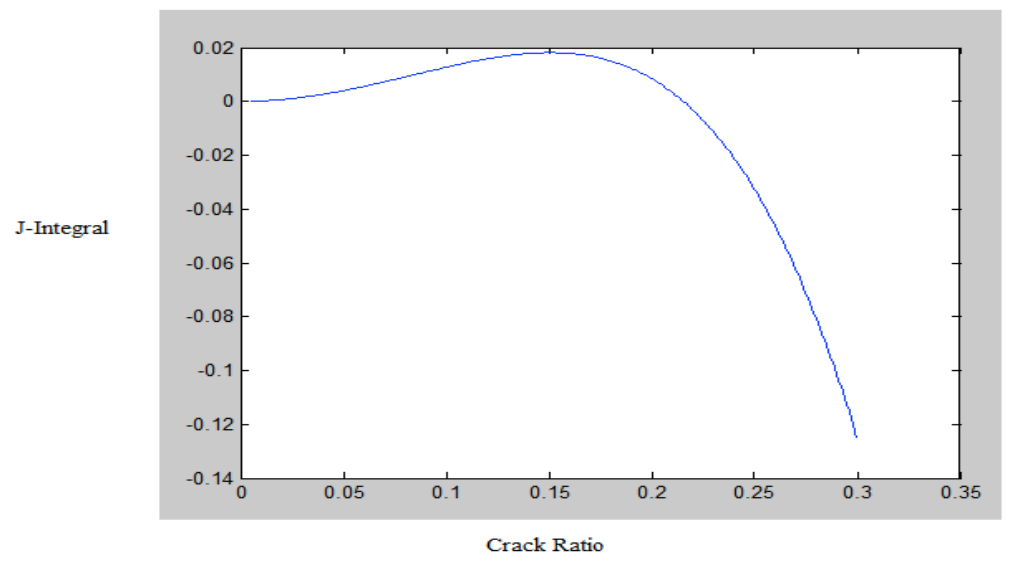

Figure 5. The J-Integral and crack ratio by Interpolasi

The results of the crack ratio optimization simulation with GA are shown in Table 3. The crack ratio reaches convergence in point 0.1355 and J-integral is 0.0175 . Thus, the optimal crack ratio is 0.1355 with the $\mathrm{J}$-integral is 0.0175 . The convergence is reached if the diference of crack ratio and J-Integral before and next step less than the smallest error value.

Table 3. The Results of Simulation of J-integral optimized by GA

\begin{tabular}{ccc}
\hline Generation & Crack Ratio & Best Fitness \\
\hline 1 & 0.1355 & 0.0175 \\
2 & 0.1355 & 0.0175 \\
3 & 0.1355 & 0.0175 \\
4 & 0.1355 & 0.0175 \\
5 & 0.1355 & 0.0175 \\
6 & 0.1355 & 0.0175 \\
7 & 0.1355 & 0.0175 \\
8 & 0.1317 & 0.0172 \\
9 & 0.1355 & 0.0175 \\
$:$ & & $:$ \\
41 & 0.1355 & 0.0175 \\
42 & 0.1355 & 0.0175 \\
43 & 0.1650 & 0.0175 \\
44 & 0.1355 & 0.0175 \\
45 & 0.1355 & 0.0175 \\
46 & 0.1355 & 0.0175 \\
47 & 0.1355 & 0.0175 \\
48 & 0.1378 & 0.0177 \\
49 & 0.1355 & 0.0175 \\
50 & 0.1310 & 0.0171 \\
\hline
\end{tabular}


The J-integral value was used to caculate SIF using Equation (2) for AISI 308L and AISI 309L. The Poisson's ratio and Young's modulus of material were used in Eq. (2) to obtain the crack ratio.

For AISI 308L, with the Poisson's ratio $(v)$ of 0.28 and Young's modulus $(E)$ of $200 \times 10^{3}$ $\mathrm{MPa}$, the SIF is

$$
K_{I}=\sqrt{\frac{200000}{1-0.28^{2}} 0.0175}=\sqrt{\frac{200000}{1-0.0784} 0.0175}=\sqrt{\frac{200000}{0.9216} 0.0175}=61.6258 \mathrm{MPa} \sqrt{m}
$$

This is less than its fracture toughness of $100 \mathrm{MPa} \sqrt{m}$. The allowed fracture toughness is in the range of $25-100 \mathrm{MPa} \sqrt{m}$ [11].

For the crack ratio of 0.3, the J-integral for Eq. (2) is obtained at 0.1250 .

$$
K_{I}=\sqrt{\frac{200000}{1-0.28} 0.1250}=\sqrt{\frac{200000}{0.9216} 0.1250}=164.70 \mathrm{MPa} \sqrt{\mathrm{m}}
$$

This exceeds the fracture toughness safety value of $100 \mathrm{MPa} \sqrt{m}$ [11].

For the crack ratio of 0.25 , the J-integral is obtained as 0.0325 and $K_{I}=465.84 \sqrt{0.0325}=83.98$ $\mathrm{MPa} \sqrt{\mathrm{m}}$. This is still less than the fracture toughness of $100 \mathrm{MPa} \sqrt{m}$.

For AISI 309L, its Poisson's ratio $(v)$ was 0.285 and its Young's modulus $(E)$ was $200 \times 10^{3}$ $\mathrm{MPa}$, with optimal the crack ratio of 0.1355 and J-integral of 0.0175 , the SIF is

$$
K_{I}=\sqrt{\frac{200000}{1-0.285^{2}} 0.0175}=\sqrt{\frac{200000}{1-0.0812} 0.0175}=\sqrt{\frac{200000}{0.9188} 0.0175}=61.7196 \mathrm{MPa} \sqrt{m}
$$

This is also less than the fracture toughness of $100 \mathrm{MPa} \sqrt{\mathrm{m}}$. Furthermore, for the crack ratio of 0.25 , J-integral is numerically evaluated as 0.0325 and the SIF is $K_{I}=466.5 \sqrt{0.0325}=84.1$ $\operatorname{MPa} \sqrt{m}$. This is also less than the fracture toughness of $100 \mathrm{MPa} \sqrt{m}$, it means still safe.

\section{CONCLUSION}

The crack ratio of PWR pressure vessel cladding with material AISI 308L and AISI 309L stainless steel have been optimized using GA. The obtained values can be used for crack detection especially in the case of fracture and in material failure, generally. It was found that the optimal crack ratio is 0.1355 with J-Integral is 0.0175 . This is the ratio of the crack depth and crack width that, if surpassed, causes material failure. The SIF for AISI 308L is 61.6258 $M P a \sqrt{m}$ and AISI 309L is $61.7196 \mathrm{MPa} \sqrt{m}$. Those are still less than the fracture toughness of each material.

\section{ACKNOWLEDGMENT}

The authors are grateful for the financial support from DIPA-BATAN. 


\section{REFERENCES}

1. Zerbst, U., Klinger, C. \& Clegg, R. Fracture mechanics as a tool in failure analysis Prospects and limitations. Eng. Fail. Anal. 2015. 55:376-410.

2. Perl, M., Steiner, M. \& Perry, J. 3-D stress intensity factors due to autofrettage for an inner radial lunular or crescentic crack in a spherical pressure vessel. Eng. Fract. Mech. 2014. 131:282-295.

3. Lee, K. H., Jhung, M. J., Kim, M. C. \& Lee, B. S. Effects of tempering and PWHT on microstructures and mechanical properties of SA508 GR.4N steel. Nucl. Eng. Technol. 2014. 46:413-422.

4. Han, Q., Wang, Y., Yin, Y. \& Wang, D. Determination of stress intensity factor for mode I fatigue crack based on finite element analysis. Eng. Fract. Mech. 2015. 138:118-126.

5. Perl, M. \& Steiner, M. 3-D stress intensity factors due to full autofrettage for inner radial or coplanar crack arrays and ring cracks in a spherical pressure vessel. Eng. Fract. Mech. 2015. 138:233-249.

6. Peng, D. \& Jones, R. A simple method for calculating the stress intensity factors for complex 3D cracks at a notch. Eng. Fract. Mech. 2016. 158:81-86.

7. Okada, H., Koya, H., Kawai, H., Li, Y. \& Osakabe, K. Computations of stress intensity factors for semi-elliptical cracks with high aspect ratios by using the tetrahedral finite element (fully automated parametric study). Eng. Fract. Mech. 2016. 158:144-166.

8. Livieri, P. \& Segala, F. Stress intensity factors for embedded elliptical cracks in cylindrical and spherical vessels. Theor. Appl. Fract. Mech. 2016. 86:260-266.

9. Mehrjoo, M., Khaji, N. \& Ghafory-Ashtiany, M. Application of genetic algorithm in crack detection of beam-like structures using a new cracked Euler-Bernoulli beam element. Appl. Soft Comput. J. 2013. 13:867-880.

10. M. Susmikanti, A. Hafid, and J. B. Sulistyo. Optimization of Residual Stress of HighTemperature Treatment Using Genetic Algorithm and Neural Network. Atom Indonesia. 2015. 41:123.

11. M. Susmikanti, R. Himawan, A. Hafid, E. Hartini. Evaluation on Mechanical Fracture of PWR Pressure Vessel and Modeling Based on Neural Network. Tri Dasa Mega 2016. 18:87.

12. Moezi, S. A., Zakeri, E., Zare, A. \& Nedaei, M. On the application of modified cuckoo optimization algorithm to the crack detection problem of cantilever Euler-Bernoulli beam. Comput. Struct. 2015. 157:42-50. 